\title{
Phosphorus biological cycle in the different Suaeda salsa marshes of the Yellow River estuary, China
}

\author{
Zhigao Sun · Xiaojie Mou $\cdot$ Hanqin Tian $\cdot$ \\ Hongli Song • Huanhuan Jiang · Jinyong Zhao • \\ Wanlong Sun $\cdot$ Wenguang Sun
}

Received: 9 October 2011 / Accepted: 20 October 2012/Published online: 15 November 2012

(C) The Author(s) 2012. This article is published with open access at Springerlink.com

\begin{abstract}
Much uncertainty exists in the phosphorus (P) cycle in the marshes of the intertidal zone. This study explored the P cycling in the two Suaeda salsa marshes [middle S. salsa marsh (MSM) and low S. salsa marsh (LSM)] of the Yellow River estuary during April 2008 to November 2009. Results showed seasonal fluctuations and vertical distributions of $\mathrm{P}$ in different $S$. salsa marsh soils, and variations in $\mathrm{P}$ content in different parts of plants due to water and salinity status. The N/P ratios of the different $S$. salsa were $9.87 \pm 1.23$ and $15.73 \pm 1.77$, respectively, indicating that plant growth in MSM was limited by N, while that in LSM was limited by both $\mathrm{N}$ and $\mathrm{P}$. The $S$. salsa litter in MSM released $\mathrm{P}$ to the environment throughout the year, while that in LSM immobilized P from the environment at all times. The $\mathrm{P}$ absorption coefficients of $S$. salsa in MSM and LSM were very low ( 0.0010 and 0.0001 , respectively), while the biological cycle coefficients were high $(0.739$ and 0.812 , respectively). The P turnovers among compartments of MSM and
\end{abstract}

Z. Sun $(\bowtie) \cdot X$. Mou $\cdot$ H. Song $\cdot$ H. Jiang $\cdot$ Wanlong Sun

Wenguang Sun

Key Laboratory of Coastal Zone Environmental Processes, Yantai Institute of Coastal Zone Research (YIC), Chinese Academy of Sciences (CAS); Shandong Provincial Key Laboratory of Coastal Zone Environmental Processes,

YICCAS, Yantai 264003, Shandong, People's Republic of China e-mail: zgsun@yic.ac.cn

H. Tian

International Center for Climate and Global Change Research, School of Forestry and Wildlife Sciences, Auburn University, Auburn, AL 36849, USA

J. Zhao

China Institute of Water Resources and Hydropower Research, Beijing 100038, People's Republic of China
LSM showed that the uptake amounts of roots were 0.4275 and $0.0469 \mathrm{~g} \mathrm{~m}^{-2}$ year ${ }^{-1}$ and the values of aboveground parts were 1.1702 and $0.1833 \mathrm{~g} \mathrm{~m}^{-2}$ year $^{-1}$, the re-translocation quantities from aboveground parts to roots were 0.8544 and $0.1452 \mathrm{~g} \mathrm{~m}^{-2}$ year $^{-1}$, the translocation amounts from roots to soil were 0.0137 and $0.0012 \mathrm{~g} \mathrm{~m}^{-2}$ year $^{-1}$, the translocation quantities from aboveground living bodies to litter were 0.3157 and $0.0381 \mathrm{~g} \mathrm{~m}^{-2}$ year $^{-1}$, and the annual return quantities from litter to soil were less than 0.0626 and $-0.0728 \mathrm{~g} \mathrm{~m}^{-2}$ year $^{-1}$ (minus represented immobilization), respectively. P was an important limiting factor in $S$. salsa marshes, especially in LSM. $S$. salsa was seemingly well adapted to the low-nutrient condition and the vulnerable habitat, and the nutrient enrichment due to the import of $\mathrm{N}$ and P from the Yellow River estuary would be a potential threat to the $S$. salsa marshes.

Keywords Phosphorus - Biological cycle $\cdot$ Suaeda salsa marsh · Yellow River estuary

\section{Introduction}

Phosphorus (P) has been regarded as a common limiting nutrient in ecosystems, which plays an important role in many biogeochemical processes (Hinsinger 2001; Zhang et al. 2005), such as participating in the composition of many P-containing compounds (nucleic acid, phospholipid, ribonucleotide and adenosine triphosphate), controlling the metabolism of carbohydrates in the photosynthesis process, and enhancing the stress-resistance and adaptation of plants (Lu 2003). P also has significant effects on other nutrient [carbon (C), nitrogen $(\mathrm{N})$ ] cycles (Newman and Lynch 2001; Tian et al. 2010), water body eutrophication and plant productivity (Compton et al. 2000; Hinsinger 2001). 
The $\mathrm{P}$ cycle is one of the most complex cycles in wetland ecosystems, which is responsible for a series of important biogeochemical processes (Qin 2008). The productivity and trophic status of wetlands are usually dependent on the concentration of $\mathrm{P}$ in waters or soils. Wetlands have often been called the 'green filter' for their P retention capability and water purification capability (Coelho et al. 2004), and about $80-90 \%$ of $\mathrm{P}$ is stored in soils due to the long turnover time of $\mathrm{P}$ in wetland ecosystems (JiménezCárceles and Álvarez-Rogel 2008).

There has been intensely increasing interest in understanding the $\mathrm{P}$ cycle in wetland ecosystems because high input of nutrient $(\mathrm{N}, \mathrm{P})$ into wetlands, along with oxic surface and anoxic subsurface zones, potentially allow $\mathrm{P}$ to play a critical role in the biogeochemistry of wetlands (Walbridge 2000). Many studies have been conducted on the processes of the $\mathrm{P}$ cycle in different wetland ecosystems, such as salt marshes (Coelho et al. 2004; Bai et al. 2007), freshwater marshes (Hogan et al. 2004; Dunne et al. 2007; Zhang et al. 2011) and peatlands (Niedermeier and Robinson 2009). Tidal marshes are very important in coastal zones, which are sensitive to global climate change and human activities. In general, most of the $\mathrm{P}$ in tidal marshes is bound to clay and silt particles or is precipitated as mineral $\mathrm{P}$, and changes in physical conditions, such as oxygen concentration, salinity or $\mathrm{pH}$ can alter this balance (Qin 2008). However, information on the processes of the $P$ cycle in tidal marshes remains limited. In addition, current studies mostly focus on a certain process of the $\mathrm{P}$ cycle, while systemic and synthetic studies are lacking. The compartment model has been widely and successfully applied in previous research and is a common approach to study the element cycles of ecosystems (Reuss and Innis 1977; Wallance et al. 1978). Most compartment model studies have, however, focused on grassland ecosystems ( $\mathrm{Li}$ and Redmann 1992; Li et al. 2003), forest ecosystems (Liu and Yu, 2005; Wu et al. 2006) and freshwater marsh ecosystems (Sun and Liu 2007; Liu and Li 2008), and information on the P cycle of tidal marshes remains scarce.

The Yellow River is well known as a sediment-laden river. Every year, approximately $1.05 \times 10^{7}$ tons of sediment is carried to the estuary (Cui et al. 2009) and deposited in the slow flowing landform, resulting in vast floodplain and special marsh landscape (Xu et al. 2002). Sediment deposition is an important process for the formation and development of tidal marshes in the Yellow River Delta. The deposition rate of sediment in the Yellow River not only affects the formation rate of tidal marshes, but also, to some extent, influences water or salinity status and the succession of plants. Tidal marsh is the main marsh type, with an area of $964.8 \mathrm{~km}^{2}$, accounting for $63.06 \%$ of the total area of the Yellow River Delta (Cui et al. 2009). Suaeda salsa is the most prevalent plant in the tidal marsh of the Yellow River estuary. As a pioneer plant, it has strong adaptations to environmental stresses, such as high salinity, flooding and sediment burial (Han et al. 2005). Suaeda salsa generally germinates in late April, blooms in July, matures in late September and completely dies in late November (Gu 1998). In the $S$. salsa distribution area, two phenotypes are generally formed due to the differences of water and salinity conditions in tidal marshes. In the middle marsh, the $S$. salsa is unfrequently and irregularly affected by the tide, so the salinity of sediment is low [electrical conductivity $(0-5 \mathrm{~cm}), 5.58 \pm 2.80 \mathrm{mS} \mathrm{cm}^{-1}$ ] (Mou et al. 2010). The leaf and stem of $S$. salsa are green during the growth period and the plant is tall (Wang et al. 2006). In the low marsh, the $S$. salsa is frequently affected by the tide, so the salinity of sediment is very high [electrical conductivity $(0-5 \mathrm{~cm}), \quad 18.07 \pm 0.43 \mathrm{mS} \mathrm{cm}^{-1}$ ] (Mou et al. 2010). The leaf and stem of $S$. salsa are generally red-violet and the plant is very short (Wang et al. 2006). However, information on elemental biogeochemical processes of the tidal marshes in the Yellow River estuary is limited and the systemic and comparative studies on the $\mathrm{P}$ cycles of the two $S$. salsa marshes are still lacking.

In this paper, the P biological cycle of the two $S$. salsa marshes in the intertidal zone of the Yellow River estuary was systemically and comparatively studied. The $S$. salsa marsh was divided into four P compartments, including aboveground living body, root, litter and soil. The purposes of this paper were: (i) to determine the distribution characteristics of $\mathrm{P}$ in the plant-soil system; (ii) to study the $\mathrm{P}$ turnovers among the compartments of $S$. salsa marsh; and (iii) to establish the $\mathrm{P}$ biological cycle compartment pattern of $S$. salsa marshes and evaluate the P cycle status.

\section{Materials and methods}

\section{Study site}

This study was conducted from April 2008 to November 2009 at two experimental plots in the $S$. salsa distribution area [middle $S$. salsa marsh (MSM), $37^{\circ} 45^{\prime} 57.0^{\prime \prime} \mathrm{N}$, $119^{\circ} 09^{\prime} 40.7^{\prime \prime} \mathrm{E}$; low $S$. salsa marsh (LSM), $37^{\circ} 46^{\prime} 38.9^{\prime \prime} \mathrm{N}$, $\left.119^{\circ} 09^{\prime} 41.4^{\prime \prime} \mathrm{E}\right]$ in the intertidal zone of the Yellow River estuary, located in the Nature Reserve of Yellow River Delta $\left(37^{\circ} 35^{\prime} \mathrm{N}-38^{\circ} 12^{\prime} \mathrm{N}, 118^{\circ} 33^{\prime} \mathrm{E}-119^{\circ} 20^{\prime} \mathrm{E}\right)$ in Dongying City, Shandong Province, China. The nature reserve is of typical continental monsoon climate with distinctive seasons; summer is warm and rainy while winter is cold. The annual average temperature is $12.1^{\circ} \mathrm{C}$, the frost-free period is 196 days, and the effective accumulated temperature is about $4,300{ }^{\circ} \mathrm{C}$. Annual evaporation is $1,962 \mathrm{~mm}$ and annual precipitation is $551.6 \mathrm{~mm}$, with about $70 \%$ of precipitation occurring between June and 
August. The soils in the study area are dominated by intrazonal tide soil and salt soil (Tian et al. 2005), and the main vegetations include Phragmites australis, S. salsa, Triarrhena sacchariflora, Myriophyllum spicatum, Tamarix chinensis and Limoninum sinense.

Study methods

\section{Collection of soil samples}

The seasonal dynamics of total phosphorus (TP) content in topsoil was studied at the two experimental plots from April to November in 2009. Ten soil samples were collected per month at a sampling depth of $0-15 \mathrm{~cm}$, and soil bulk densities were determined. The vertical distributions of TP content in the soil profile were studied in August 2008. Three soil profiles (depth: $60 \mathrm{~cm}$ ) were sampled at each experimental plot at $10 \mathrm{~cm}$ intervals, with 18 samples in total. The bulk density of each soil layer was determined simultaneously. The $\mathrm{P}$ stock $\left(T_{n}, \mathrm{~kg} \mathrm{~m}^{-2}\right)$ in soil was calculated by Eq. (1):

$T_{n}=\sum_{i=1}^{n} W_{i} \times P_{i} \times h / 10$

where $W_{i}\left(\mathrm{~g} \mathrm{~cm}^{-3}\right)$ is the soil bulk density of the $i$ layer, $P_{i}(\%)$ is the TP content in the $i$ layer and $h$ is soil depth $(10 \mathrm{~cm})$.

\section{Determination of litter and biomass}

Litter production, aboveground biomass (AGB) and belowground biomass (BGB) were determined using quadrat method $(50 \mathrm{~cm} \times 50 \mathrm{~cm}$, five replications) at the two experimental plots from May to November in 2008, with a sampling frequency of 20 days. On the sampling dates, the aboveground part of plant was clipped near the ground, and the stem, leaf and standing dead litter were separated immediately in the laboratory. The new litter distributed in the quadrat was also collected. Roots in the quadrat were dug out and washed carefully. All samples were weighed after being dried at $80{ }^{\circ} \mathrm{C}$ for $48 \mathrm{~h}$. In the growing season, because little parts of the plant or the litter could be carried away or redistributed in tidal marshes during the ebb and flow, the AGB and litter production were standing crops.

\section{Determination of litter decomposition rates}

Litter decomposition was studied with a litterbag technique at the two experimental plots from April 2008 to November 2009. The two types of $S$. salsa litter were washed in distilled water, cut into $10 \mathrm{~cm}$ segments and oven-dried at $80{ }^{\circ} \mathrm{C}$ for $48 \mathrm{~h}$. Each $20 \mathrm{~cm} \times 20 \mathrm{~cm}$ litterbag was made of nylon netting $(0.5 \mathrm{~mm}$ mesh) and filled with $15 \mathrm{~g}$ litter (oven-dried weight). On 21 April 2008, the litterbags were randomly placed on each experimental plot of $S$. salsa community. The experiment included nine sampling times (with different intervals), and on each sampling date, three or four litterbags were retrieved from each plot. After retrieval, these litterbags were immediately taken back to the laboratory, and the plant roots, lichen, sediment and macro-invertebrates were removed from the remaining litter. All litterbags were further cleaned gently in deionized water, and weighed after being dried at $80{ }^{\circ} \mathrm{C}$ for $48 \mathrm{~h}$. Litter mass loss $(R, \%)$ and decomposition rate $\left(\mathrm{d}^{-1}\right)$ were calculated by Eqs. (2)-(3) (Olson 1963; Liu et al. 2000).

$R=\left[\left(W_{t}-W_{0}\right) / W_{0}\right] \times 100 \%$

$W_{t} / W_{0}=e^{-k t}$

where $W_{O}(\mathrm{~g})$ is the original dry mass, $W_{t}(\mathrm{~g})$ is the dry mass at time " $t$ "; $k$ is the decay constant and $t$ (d) is decomposition time in days. After 1 year decomposition, the annual $\mathrm{P}$ translocation amount from litter to soil was calculated by the change of $\mathrm{P}$ stock in litter.

\section{Measurement of soil and plant samples}

All soil and plant samples were ground $(<0.25 \mathrm{~mm})$ using a Wiely mill and analyzed for TC, TN contents by element analyzer (Elementar Vario Micro, German) and TP content by molybdate-ascorbic acid colorimetry (digested by $\mathrm{H}_{2} \mathrm{SO}_{4}-\mathrm{H}_{2} \mathrm{O}_{2}$ ) (The Committee of Agro-chemistry of the Chinese Society of Soil Science 1983).

\section{Calculation of $P$ stock and turnover}

The $\mathrm{P}$ biological cycle characteristics of $S$. salsa marsh ecosystem can be expressed by absorption coefficient $(A)$ and cycle coefficient $(C)$, and their calculations were based on Eqs. (4)-(5) (Chen and Lindley 1983):

$A=\mathrm{PAP} / \mathrm{SP}$

$C=\mathrm{PRP} / \mathrm{PAP}$

where PAP $\left(\mathrm{g} \mathrm{m}^{-2}\right.$ year $\left.^{-1}\right)$ is the $\mathrm{P}$ absorption amount of plant, PRP $\left(\mathrm{g} \mathrm{m}^{-2}\right.$ year $\left.^{-1}\right)$ is the $\mathrm{P}$ return amount of plant and $\mathrm{SP}\left(\mathrm{g} \mathrm{m}^{-2}\right)$ is the $\mathrm{P}$ stock in soil $(0-60 \mathrm{~cm})$.

According to the calculation method of Li and Redmann (1992), the $\mathrm{P}$ stocks in plant compartments $\left(P_{n}, \mathrm{~g} \mathrm{~m}^{-2}\right)$ and the $\mathrm{P}$ turnovers among plant compartments $\left(F_{a}, \mathrm{~g} \mathrm{~m}^{-2}\right.$ year $^{-1}$ ) were calculated by Eqs. (6)-(7):

$P_{n}=C_{n} B_{n}$

$F_{a}=C_{a} B_{a}$

where $C_{n}\left(\mathrm{mg} \mathrm{kg}^{-1}\right)$ is the $\mathrm{P}$ content of compartment, $B_{n}$ $\left(\mathrm{g} \mathrm{m}^{-2}\right)$ is the biomass of compartment, $C_{a}\left(\mathrm{mg} \mathrm{kg}^{-1}\right)$ is the $\mathrm{P}$ content as AGB reaches maximum and $B_{a}\left(\mathrm{~g} \mathrm{~m}^{-2}\right)$ is the maximum AGB. 
Litter P stock $\left(F_{d a}, \mathrm{~g} \mathrm{~m}^{-2}\right)$ in aboveground dead plant, the $\mathrm{P}$ re-translocation quantities from aboveground parts to roots $\left(F_{r t}, \mathrm{~g} \mathrm{~m}^{-2}\right.$ year $\left.^{-1}\right)$, and the $\mathrm{P}$ uptake quantities of roots $\left(F_{r}, \mathrm{~g} \mathrm{~m}^{-2}\right.$ year $\left.^{-1}\right)$ were calculated by Eqs. (8)-(10):

$F_{d a}=C_{d} B_{a}$

$F_{r t}=F_{a}-F_{d a}$

$F_{r}=F_{a}-F_{r t}+\Delta P_{u}$

where $C_{d}\left(\mathrm{mg} \mathrm{kg}^{-1}\right)$ is the $\mathrm{P}$ content of aboveground dead plant, $B_{a}\left(\mathrm{~g} \mathrm{~m}^{-2}\right)$ is the quantity of aboveground dead plant and $\Delta P_{u}\left(\mathrm{~g} \mathrm{~m}^{-2}\right)$ is the net $\mathrm{P}$ increment of root in the growing season.

The $\mathrm{P}$ translocation amounts from litter to soil $\left(F_{s}, \mathrm{~g} \mathrm{~m}^{-2}\right.$ year $\left.^{-1}\right)$ and from roots to soil $\left(F_{T}, \mathrm{~g} \mathrm{~m}^{-2}\right.$ year $^{-1}$ ) were calculated by Eqs. (11)-(13):

$F_{s}=F_{l}-F_{y}$

$F_{T}=T \times B_{\mathrm{Max}} \times C_{\mathrm{Max}}$

$T=P_{m} / B_{\text {Max }}$

where $F_{l}\left(\mathrm{~g} \mathrm{~m}^{-2}\right)$ is composed of $F_{d a}$ and $F_{p}, F_{p}\left(\mathrm{~g} \mathrm{~m}^{-2}\right)$ is the $\mathrm{P}$ stock in un-decomposed litter previously accumulated in situ, $F_{y}\left(\mathrm{~g} \mathrm{~m}^{-2}\right)$ is the $\mathrm{P}$ stock in un-decomposed litter after a period of time, $T(\%)$ is the turnover rate of root (Dahlman and Kucera 1965), $P_{m}\left(\mathrm{~g} \mathrm{~m}^{-2}\right)$ is the deficit of maximum biomass and minimum biomass of root, $B_{\max }$ $\left(\mathrm{g} \mathrm{m}^{-2}\right)$ is the maximum BGB and $C_{\max }\left(\mathrm{mg} \mathrm{kg}^{-1}\right)$ is the $\mathrm{P}$ content as root biomass reaches maximum.

\section{Statistical analysis}

The samples were presented as means of the replications, with standard error (SE). Statistical significance of differences at $p<0.05$ between samples were analyzed using analysis of variance (ANOVA).

\section{Results and discussion}

$\mathrm{P}$ dynamics, distribution and stock in soils

\section{Seasonal dynamics of $P$ in topsoil}

Although the TP contents in MSM and LSM topsoil had similar seasonal variations, neither of them was significant ( $p>0.05$, Fig. 1). Both of them increased from 25 April to 26 May (LSM) or 27 June (MSM) and significantly decreased until 25 August (LSM) or 25 September (MSM). After that, both increased again and then declined significantly. The maximum and minimum in MSM topsoil were observed on 27 June $\left(823.38 \pm 45.65 \mathrm{mg} \mathrm{kg}^{-1}\right)$ and 12 November $\left(515.67 \pm 130.19 \mathrm{mg} \mathrm{kg}^{-1}\right)$, while those in LSM topsoil

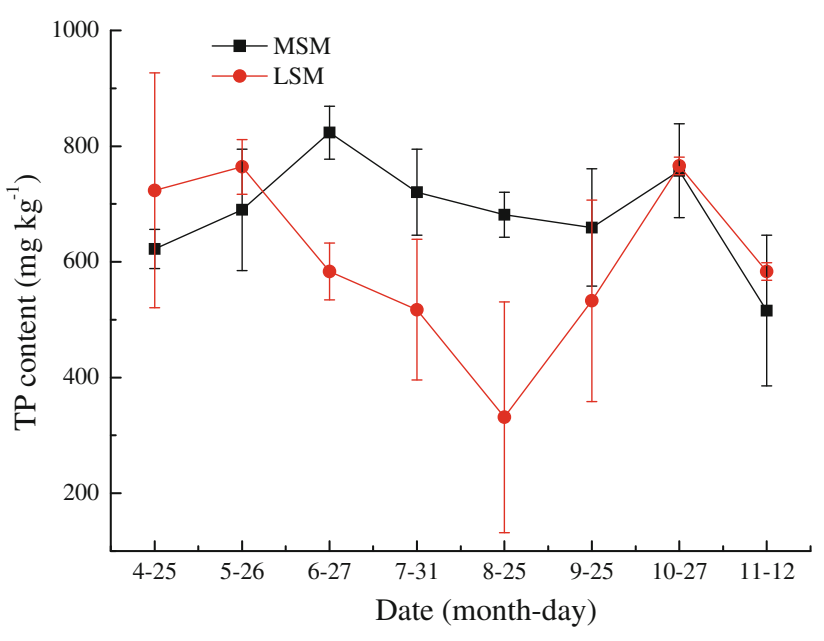

Fig. 1 Seasonal dynamics of TP content in topsoil $(0-15 \mathrm{~cm})$ of Suaeda salsa marshes. Values are means $( \pm \mathrm{SE}, n=10)$; TP total phosphorus content, MSM middle $S$. salsa marsh, LSM low $S$. salsa marsh

occurred on 27 October $\left(765.90 \pm 15.22 \mathrm{mg} \mathrm{kg}^{-1}\right)$ and 25 August $\left(331.38 \pm 199.51 \mathrm{mg} \mathrm{kg}^{-1}\right)$, respectively. The seasonal variations of TP content in MSM and LSM topsoil were probably related to the distribution of soil organic matter (Bai et al. 2007; Qin et al. 2007), the mineralization of organic $P$ (Qin et al. 2007; Xiao et al. 2011), plant absorption (Qin et al. 2006a), and the ebb and flow of the tide (Mou 2010) in different periods. The values in MSM topsoil in the summer were generally higher than those in LSM topsoil, while in the early spring and late autumn, the latter was much higher. The discrepancy of TP content in MSM and LSM topsoil was mainly related to the difference of water conditions. Compared with MSM, the LSM was more frequently affected by the tide (Mou 2010), which was favorable for the formation of anoxic conditions in topsoil. Under anoxic conditions, the iron oxide forms were directly correlated with the adsorption and desorption processes of $\mathrm{P}$, which had significant influences on P dynamics and its availability in topsoil (Qin et al. 2006b). In addition, the organic matter in LSM topsoil $(0.63 \%)$ was generally lower than that in MSM topsoil (1.01\%) (Mou et al. 2010), which was not favorable for the conservation of $\mathrm{P}$ (Qin et al. 2007). Studies showed that the P stocks in topsoil $(0-15 \mathrm{~cm})$ of MSM and LSM during the growing season were 70.03-111.82 and 53.59$123.87 \mathrm{~g} \mathrm{~m}^{-2}$, respectively.

\section{Vertical distribution of $P$ in soil}

Similar vertical distributions of TP content were observed in the soil profile $(0-60 \mathrm{~cm})$ of MSM and LSM (Fig. 2a). For both, the TP content decreased at $0-30 \mathrm{~cm}$ depth and increased significantly at $30-60 \mathrm{~cm}$ depth, with the maximums $\quad\left(551.56 \pm 0.94 \mathrm{mg} \mathrm{kg}^{-1}\right.$ for MSM and 
Fig. 2 Vertical distributions of TP content (a) and $P$ stock (b) in the soil profile $(0-60 \mathrm{~cm})$ of Suaeda salsa marshes. Values are means $( \pm \mathrm{SE}, n=3)$. MSM middle $S$. salsa marsh, LSM low S. salsa marsh

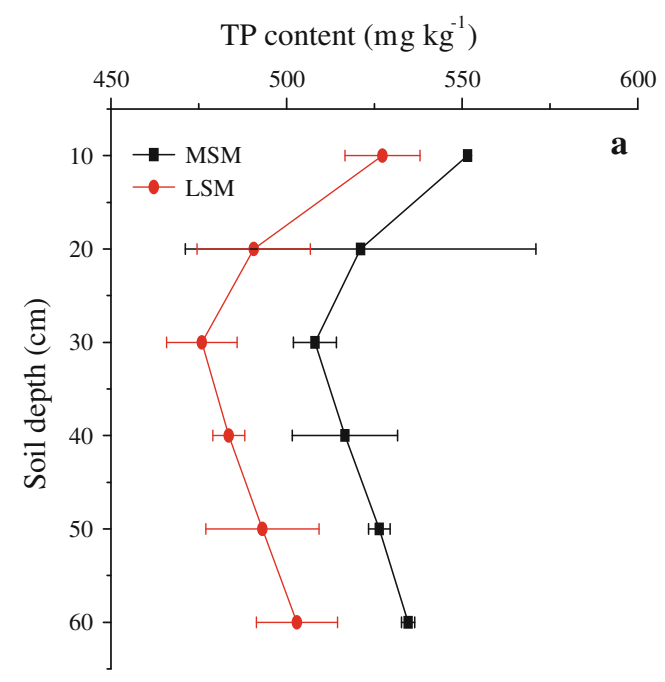

$527.32 \pm 10.67 \mathrm{mg} \mathrm{kg}^{-1}$ for LSM) and minimums $\left(508.08 \pm 6.13 \mathrm{mg} \mathrm{kg}^{-1}\right.$ for MSM and $475.88 \pm$ $10.03 \mathrm{mg} \mathrm{kg}^{-1}$ for LSM) being observed at $10 \mathrm{~cm}$ and $30 \mathrm{~cm}$ depths, respectively. Likewise, similar vertical distributions of $\mathrm{P}$ stock were observed in the soil profile $(0-60 \mathrm{~cm})$ of MSM and LSM except for the values at $30 \mathrm{~cm}$ depth (Fig. 2b), with the minimums $\left(0.061 \mathrm{~g} \mathrm{~m}^{-2}\right.$ for MSM and $0.077 \mathrm{~g} \mathrm{~m}^{-2}$ for LSM) being observed at $40 \mathrm{~cm}$ and $30 \mathrm{~cm}$ depths, respectively. The vertical variations of TP content and P stock were generally dependent on the spatial heterogeneity of soil organic matter (Bai et al. 2007) and the effects of changes in soil water conditions (Qin et al. 2006b; Xiao et al. 2012) resulting from the tide. Significantly higher TP content was observed in MSM compared to LSM $(1.062 \pm 0.003$-fold, $p<0.01)$, whereas significantly lower $\mathrm{P}$ stock occurred in MSM compared to LSM $(0.889 \pm 0.032$-fold, $p<0.05)$. The low TP content in LSM, as mentioned previously, was mainly dependent on the water conditions and organic matter in different soil layers, while high P stocks in LSM were mainly related to the high bulk density of different soil layers (Mou 2010). Studies indicated that, in August 2008, the total P stocks in MSM and LSM soils $(0-60 \mathrm{~cm})$ were 438.83 and $492.27 \mathrm{~g} \mathrm{~m}^{-2}$, respectively.

$\mathrm{P}$ dynamics, stock and turnover in plants

\section{Dynamics of plant biomass}

Significant seasonal variations of AGB and BGB of S. salsa were observed in MSM and LSM (Fig. 3). In MSM, both increased with the improvement of hydrothermal conditions since 17 May, and reached the maximums on 31 August $\left(902.08 \pm 87.57 \mathrm{~g} \mathrm{~m}^{-2}\right)$ and 9 August $\left(149.87 \pm 4.84 \mathrm{~g} \mathrm{~m}^{-2}\right)$, respectively. After that, both decreased gradually with the coming of autumn, with the minimums $\quad\left(63.00 \pm 5.88\right.$ and $\quad 69.74 \pm 15.78 \mathrm{~g} \mathrm{~m}^{-2}$, respectively) occurring on 15 November. In LSM, both also increased since 17 May, but reached the maximums $\left(253.28 \pm 26.93\right.$ and $23.11 \pm 1.23 \mathrm{~g} \mathrm{~m}^{-2}$, respectively) on 31 August. Then, both decreased gradually and reached the minimums $\left(136.45 \pm 13.53\right.$ and $13.39 \pm 1.37 \mathrm{~g} \mathrm{~m}^{-2}$, respectively) on 15 November. Significantly higher AGB and BGB of $S$. salsa were observed in MSM compared to LSM $(3.58 \pm 0.52$ and $5.46 \pm 0.54$-fold, respectively, $p<0.05$ ). Moreover, significant seasonal variations of stem and leaf biomass of $S$. salsa were also observed in MSM and LSM (Fig. 3), with the maximums $\left(661.22 \pm 51.98\right.$ and $240.86 \pm 38.57 \mathrm{~g} \mathrm{~m}^{-2}$ for MSM, and $111.37 \pm 11.27$ and $141.91 \pm 17.43 \mathrm{~g} \mathrm{~m}^{-2}$ for LSM) being observed on 31 August. The stem and leaf biomass of S. salsa in MSM were also higher than those in LSM $(4.90 \pm 0.88$ and $2.41 \pm 0.33$-fold, respectively), but only the difference of stem biomass between them was significant $(p<0.05)$.

Water and salinity conditions are the most typical environmental factors in the intertidal zone of the Yellow River estuary, which might influence plant biomass directly. Current studies have shown that soil moisture was an important factor to influence the biomass accumulation of plants. Wang et al. (2008) indicated that proper water stress was favorable for the biomass accumulation of Calamagrostis angustifolia in the Sanjiang Plain, while severe water stress had significant restraint on that of Zoysia (Wang et al. 2009). He and $\mathrm{Li}$ (2008) also found that salinity stress had significant effects on the growth, biomass accumulation and allocation of Salsola nitraria and Halogeton glomeratus. Similar conclusions were drawn by Rawat and Banerjee (1998) who showed that low salt concentrations generally stimulated the growth and biomass production of Dalbergia sissoo, while high salt concentrations were significantly inhibiting. The $S$. salsa in 

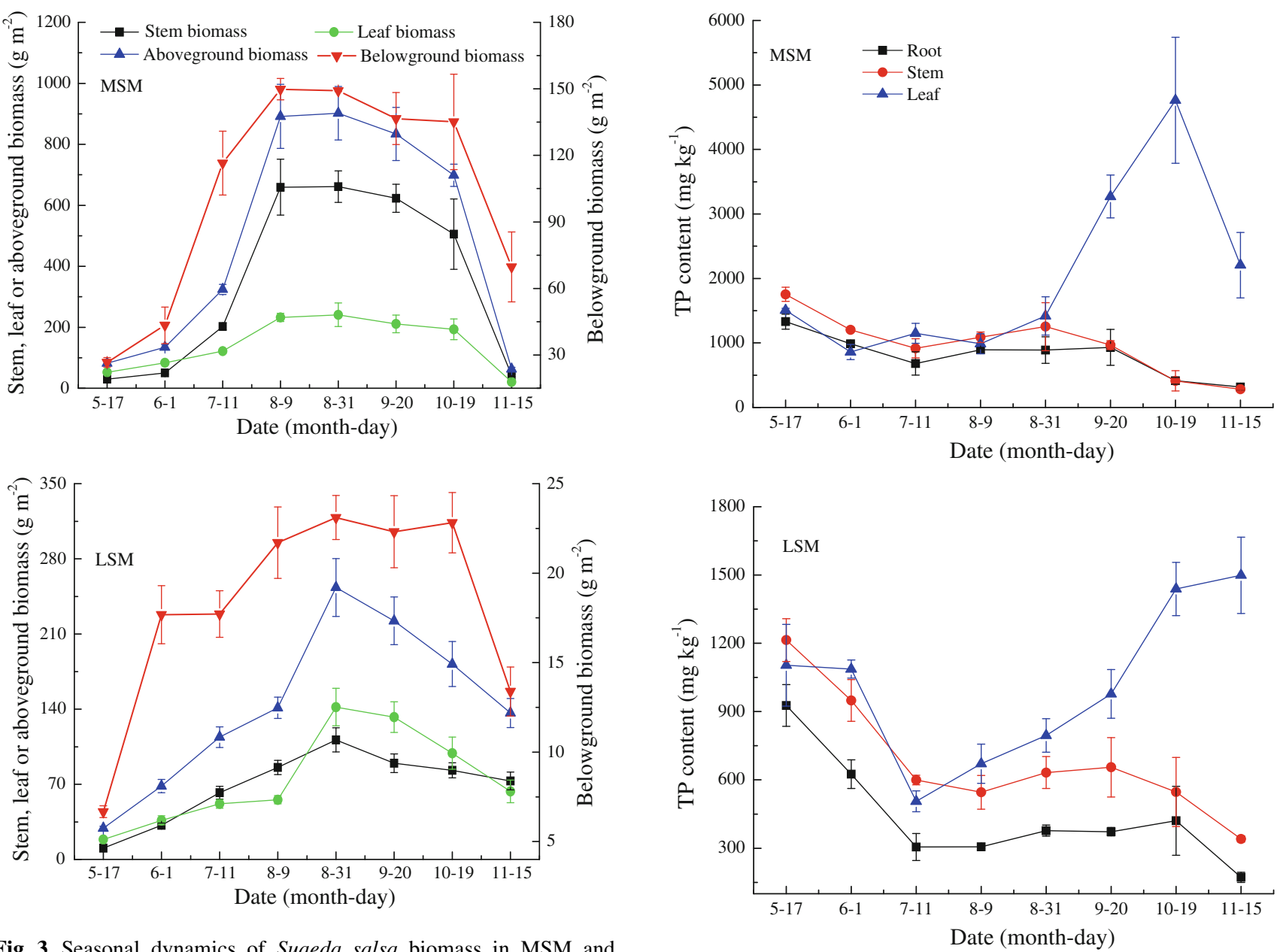

Fig. 3 Seasonal dynamics of Suaeda salsa biomass in MSM and LSM. Values are means ( \pm SE, $n=5)$. MSM middle $S$. salsa marsh, LSM low $S$. salsa marsh

LSM was more frequently affected by ocean currents and tides compared to MSM (Ruan et al. 2008), and it generally confronted both severe salinity stress and seawater inundation stress, which caused its low biomass.

\section{Dynamics of $P$ content in plants}

There were similar variations of TP content in the root and stem of S. salsa in MSM and LSM (Fig. 4). Both were high at the initial stage, after which the values generally decreased and reached the minimums $(317.11 \pm 49.36$ and $282.38 \pm 17.73 \mathrm{mg} \mathrm{kg}^{-1}$ for MSM, and $172.15 \pm 22.29$ and $340.77 \pm 13.28 \mathrm{mg} \mathrm{kg}^{-1}$ for LSM) on 15 November. Fluctuations of TP content were observed in the leaves of S. salsa in MSM and LSM (Fig. 4). In MSM, the values in the leaves had no significant change before 31 August, after which the values increased significantly and reached the maximums $\left(4,763.87 \pm 977.67 \mathrm{mg} \mathrm{kg}^{-1}\right)$ on 19 October. By comparison, the values in the leaves in LSM decreased significantly before 11 July and increased from 11 July to

Fig. 4 Seasonal dynamics of TP content in different parts of Suaeda salsa. Values are means ( $\pm \mathrm{SE}, n=3)$. MSM middle $S$. salsa marsh, LSM low S. salsa marsh

15 November, with the minimum $(505.63 \pm$ $\left.45.76 \mathrm{mg} \mathrm{kg}^{-1}\right)$ and maximum $(1,498.73 \pm 167.55 \mathrm{mg}$ $\mathrm{kg}^{-1}$ ) being observed on 11 July and 15 November, respectively. The fluctuation of TP content in the leaves before 31 August was mainly related to the 'dilution effect' caused by biomass increase (Sun et al. 2007), and then, the increase of TP content was correlated with the P transfer mechanism from root or stem to leaf and seed during seed growth in autumn. The TP content in different parts of $S$. salsa in MSM and LSM differed significantly ( $p<0.05)$, in the order of leaf $>$ stem $>$ root, indicating that the $\mathrm{P}$ was mainly accumulated in the leaves. Although the TP content in the root, stem and leaf of S. salsa in MSM were higher than those in $\operatorname{LSM}(2.12 \pm 0.20,1.62 \pm 0.12$, and $2.15 \pm 0.33$-fold, respectively); only the values in root between them had significant difference $(p<0.05)$.

As the most typical environmental factors in the Yellow River estuary, water and salinity conditions also might influence the accumulation of $\mathrm{P}$ in plants directly. Braekke 
(1990) showed that the changes in water condition (drainage) occurring in Scots pine (Pinus sylvestris) and Norway spruce (Picea abies) wetlands had important effects on nutrient ( $N, P$, and $\mathrm{K}$ ) accumulation in AGB. Qin (2008) indicated that water condition was the key factor to induce the significant differences of $\mathrm{P}$ allocation between typical meadow $C$. angustifolia and marsh meadow $C$. angustifolia. Stribling and Cornwell (2001) also found that the salinity gradient in the Chesapeake Bay significantly affected the seasonal dynamics of $\mathrm{N}$ and $\mathrm{P}$ in the shoots of Spartina alterniflora. The growth rhythm and ecological characteristics of plants might also affect $\mathrm{P}$ accumulation (Bragato et al. 2006). In this study, the S. salsa in the Yellow River estuary formed two phenotypes resulting from the differences of water and salinity conditions. As mentioned previously, the growth rhythms of the two phenotypes were different, which, to some extent, influenced the seasonal dynamics of $\mathrm{P}$ in $S$. salsa. In addition, many studies have shown that the succulence degree (Liu et al. 2006), peroxidase content (Wang et al. 2006), pigment accumulation and photosynthesis (Ruan et al. 2008) of the two phenotypes' leaves were significantly different, which might affect the absorption and allocation of $\mathrm{P}$ greatly.

Tessier and Raynal (2003) indicated that the N/P ratio was an effective indicator to estimate nutrient limitation and $\mathrm{N}$ saturation. Koerselman and Meuleman (1996) found that the growth of marsh plants was limited by $\mathrm{N}$ if the N/P ratio was less than 14. If the N/P ratio was between 14 and 16, the growth was limited by both $\mathrm{N}$ and $\mathrm{P}$. If the N/P ratio was more than 16 , the growth was limited by P. The relationship was applied to discussing the nutrient limitations of $S$. salsa in MSM and LSM. Results showed that the N/P ratios in S. salsa of MSM were mostly less than 14 in the growing season (average N/P ratio: $9.87 \pm 1.23$ ), indicating that plant growth was limited by $\mathrm{N}$ (Table 1). Differently, the $\mathrm{N} / \mathrm{P}$ ratios in $S$. salsa of LSM in late spring were less than 16, which implied that plant growth was limited by both $\mathrm{N}$ and $\mathrm{P}$. In summer, the N/P ratios were more than 16, suggesting that plant growth was limited by P. From late summer to early winter, the N/P ratios were less than 14 , indicating that plant growth was limited by $\mathrm{N}$ (Table 1 ). The average N/P ratio $(15.73 \pm 1.77)$ in the growing season was less than 16 (Table 1), indicating that S. salsa in LSM was generally limited by both $\mathrm{N}$ and $\mathrm{P}$, but the limitation of $\mathrm{P}$ was more significant. Moreover, the N/P ratios in different parts of the plant changed significantly during the growing season, which was mainly dependent on the nutrient absorption status of the plants and the nutrient supply status of soil in different periods. Studies showed that the P stocks in root, stem and leaf of S. salsa in MSM and LSM were 0.0221-0.1339, $0.0120-0.8283, \quad 0.0451-0.9204$ and 0.0023-0.0111, $0.0128-0.0704,0.0204-0.1424 \mathrm{~g} \mathrm{~m}^{-2}$, respectively. The $\mathrm{P}$ uptake amounts of aboveground parts were 1.1702 and $0.1833 \mathrm{~g} \mathrm{~m}^{-2}$ year $^{-1}$, the $\mathrm{P}$ uptake quantities of roots were 0.4275 and $0.0469 \mathrm{~g} \mathrm{~m}^{-2}$ year $^{-1}$, the $\mathrm{P}$ re-translocation amounts from aboveground parts to roots were 0.8544 and $0.1452 \mathrm{~g} \mathrm{~m}^{-2}$ year $^{-1}$, and the $\mathrm{P}$ translocation quantities from roots to soil were 0.0137 and $0.0012 \mathrm{~g} \mathrm{~m}^{-2}$ year $^{-1}$, respectively.

\section{Dynamics of litter production and $P$ content in litter}

Similar changes of $S$. salsa litter production were observed in MSM and LSM (Fig. 5). Both of them were low at the initial stage, after which the values generally increased and reached maximums $\quad\left(579.90 \pm 98.91\right.$ and $46.25 \pm 5.52 \mathrm{~g} \mathrm{~m}^{-2}$, respectively) at the final stage. Because the $S$. salsa in MSM and LSM did not completely die on 15 November, the actual litter productions were slightly more than the above values. In fact, the $S$. salsa in MSM produced significant amounts of litter at the end of the growing season, and the low litter production determined on 19 October might be related to the low litter standing crop resulting from the strong scouring action of the tide. The low litter production of S. salsa in LSM in the growing season was mainly correlated with its low biomass and the strong scouring action of the tide. Although the litter production of $S$. salsa in LSM was much lower than that in MSM, they had no significant difference $(p>0.05)$. Different seasonal dynamics of TP content were observed in S. salsa litter in MSM and LSM (Fig. 5). Both of them decreased significantly from 17 May to 11 July, and then, the variations were opposite, with the maximums $(1,507.92 \pm$ $15.99 \mathrm{mg} \mathrm{kg}^{-1}$ for MSM and 1,103.80 $\pm 103.68 \mathrm{mg} \mathrm{kg}^{-1}$ for LSM) and minimums (533.88 $\pm 102.32 \mathrm{mg} \mathrm{kg}^{-1}$ for MSM and $342.68 \pm 25.50 \mathrm{mg} \mathrm{kg}^{-1}$ for LSM) being observed on 17 May and 11 July, respectively. Although the TP content in $S$. salsa litter in MSM was generally higher than that in LSM (1.62 \pm 0.16 -fold); they had no significant difference $(p>0.05)$. The variations of TP content in $S$. salsa litter were mainly related to the different $\mathrm{P}$ translocation mechanisms when aboveground parts withered (Mou et al. 2010). Studies showed that the P stocks in $S$. salsa litter in MSM and LSM were 0.0005-0.3157 and 0.0002$0.0381 \mathrm{~g} \mathrm{~m}^{-2}$, respectively, and the $\mathrm{P}$ translocation quantities from aboveground living bodies to litter were 0.3157 and $0.0381 \mathrm{~g} \mathrm{~m}^{-2}$ year $^{-1}$, respectively.

\section{Dynamics of litter decomposition and $P$ content in litter}

The mass loss of $S$. salsa litter in MSM and LSM generally increased during decomposition, and the local decrease was related to the determinate error (Fig. 6). Both litter masses decreased rapidly from April to November in 2008 (0-207 days), accounting for 51.29 and $75.81 \%$ of the total loss in the experiment, respectively, which was 
Table 1 Dynamics of N/P ratio in different parts of Suaeda salsa

\begin{tabular}{|c|c|c|c|c|c|c|c|c|c|c|}
\hline \multirow[t]{2}{*}{ Type } & \multirow[t]{2}{*}{ Item } & \multicolumn{8}{|l|}{ Date } & \multirow[t]{2}{*}{ Mean value $( \pm \mathrm{SE})$} \\
\hline & & $5-17$ & $6-1$ & $7-11$ & $8-9$ & $8-31$ & $9-20$ & $10-19$ & $11-15$ & \\
\hline \multirow[t]{4}{*}{ MSM } & Root & 9.13 & 7.31 & 8.74 & 5.71 & 5.66 & 5.28 & 8.86 & 15.05 & $8.22 \pm 1.12$ \\
\hline & Stem & 11.07 & 7.89 & 11.78 & 5.03 & 4.68 & 4.96 & 11.68 & 16.54 & $9.20 \pm 1.51$ \\
\hline & Leaf & 16.93 & 17.19 & 20.58 & 22.31 & 12.54 & 7.05 & 4.97 & 11.53 & $14.14 \pm 2.19$ \\
\hline & Plant & 13.53 & 10.97 & 14.02 & 8.64 & 6.82 & 5.93 & 5.91 & 13.12 & $9.87 \pm 1.23$ \\
\hline \multirow[t]{4}{*}{ LSM } & Root & 10.58 & 15.57 & 26.50 & 15.99 & 12.27 & 12.89 & 9.87 & 21.35 & $15.63 \pm 2.02$ \\
\hline & Stem & 13.05 & 12.94 & 23.05 & 18.67 & 13.71 & 14.15 & 12.96 & 16.93 & $15.68 \pm 1.29$ \\
\hline & Leaf & 18.36 & 15.24 & 32.59 & 20.82 & 14.21 & 10.87 & 11.15 & 11.93 & $16.90 \pm 2.56$ \\
\hline & Plant & 15.31 & 14.56 & 26.50 & 19.30 & 13.89 & 11.72 & 11.39 & 13.17 & $15.73 \pm 1.77$ \\
\hline
\end{tabular}

MSM middle S. salsa marsh, LSM low S. salsa marsh

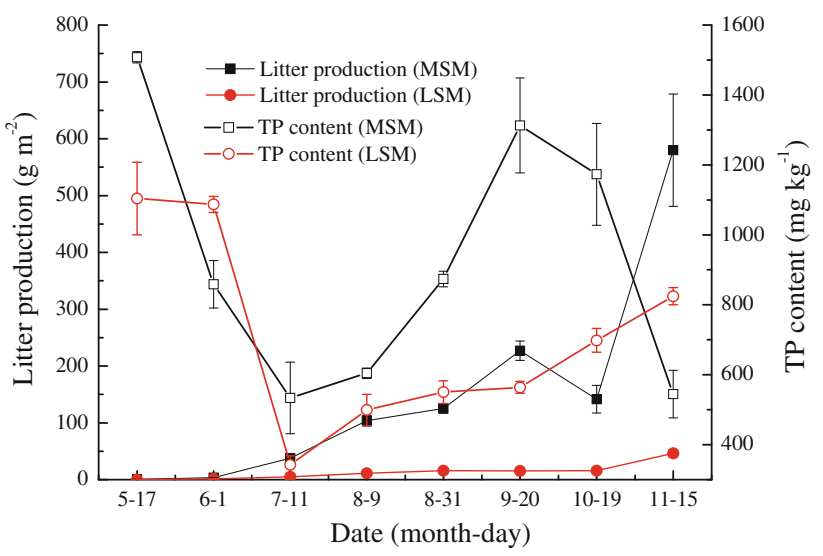

Fig. 5 Seasonal dynamics of Suaeda salsa litter production and TP content in litter. Values are means ( $\pm \mathrm{SE}, n=3)$. MSM middle $S$. salsa marsh, LSM low $S$. salsa marsh

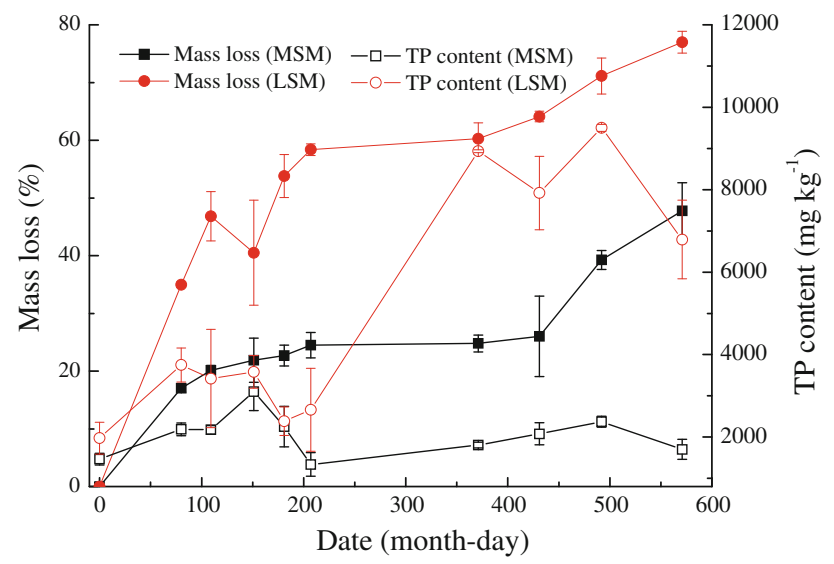

Fig. 6 Dynamics of mass loss and TP content during Suaeda salsa litter decomposition. Values are means $( \pm \mathrm{SE}, n=3)$. MSM middle S. salsa marsh, LSM low S. salsa marsh

mainly dependent on the hydrothermal condition during the growing season. From November 2008 to April 2009 (207-371 days), both the masses decreased slowly due to the low temperature and the mass loss only increased by 0.28 and $1.92 \%$, respectively. After April 2009 (371 days), both of the mass losses rapidly increased, and mass losses reached $47.78 \pm 4.86$ and $77.00 \pm 1.88 \%$ after 571 days, respectively. In general, significantly higher S. salsa litter mass losses were observed in LSM compared to MSM during decomposition (2.14 \pm 0.11 -fold, $p<0.01)$. The TP content in $S$. salsa litter in MSM increased significantly from 0 to 151 days and then decreased rapidly until 207 days. After that, the values gradually increased from 207 to 492 days and decreased until 571 days (Fig. 6). By contrast, the variations of TP content in $S$. salsa litter in LSM were more complex, with the high values being observed from 371 to 571 days (Fig. 6). The variations of $\mathrm{C} / \mathrm{P}$ ratios in $S$. salsa litter in MSM and LSM were opposite to those of the corresponding TP contents (Fig. 6; Table 2) and significant negative correlations $(r=-0.898, p<0.01 ; r=-0.939$, $p<0.01$, respectively) occurred between them, indicating that $\mathrm{C} / \mathrm{P}$ ratios might have significant influence on the $\mathrm{P}$ dynamics of $S$. salsa litter during decomposition. This result was similar to the conclusion reported by Qin (2008). In addition, the TP content in $S$. salsa litter in MSM and LSM during decomposition was 91.23-211.55 and $120.75-481.16 \%$ of the initial value, respectively, which implied that $\mathrm{P}$ might accumulate in the litter most of the time (Fig. 6). Similar results were also reported by Davis (1991) who found that the $\mathrm{N}$ and $\mathrm{P}$ accumulated in Cladium jamaicense and Typha domingensis litter during the decomposition experiment. Nielsen and Andersen (2003) indicated that the remaining $P$ in the mangrove leaf litter increased with time of decomposition to 174 and $220 \%$ of the initial amount in the litter in sand flat and mangrove sediment, respectively, although about $50 \%$ of the dry weight had been lost. The incorporation of $\mathrm{P}$ into the litter was probably associated with humic acids and metal bridging, especially caused by iron (Fe), which also accumulated in considerable amounts in the litter (Nielsen and Andersen 2003). In addition, the increase 
Table 2 Dynamics of C/P ratio in Suaeda salsa litter in MSM and LSM during decomposition

\begin{tabular}{|c|c|c|c|c|c|c|c|}
\hline \multirow{2}{*}{$\begin{array}{l}\text { Sampling date } \\
\text { (yyyy-mm-dd) }\end{array}$} & \multirow{2}{*}{$\begin{array}{l}\text { Decomposition } \\
\text { time (day) }\end{array}$} & \multicolumn{2}{|c|}{$\mathrm{C} / \mathrm{P}($ mean $\pm \mathrm{SE}, n=3)$} & \multirow{2}{*}{$\begin{array}{l}\text { Sampling date } \\
\text { (yyyy-mm-dd) }\end{array}$} & \multirow{2}{*}{$\begin{array}{l}\text { Decomposition } \\
\text { time (day) }\end{array}$} & \multicolumn{2}{|c|}{$\mathrm{C} / \mathrm{P}($ mean $\pm \mathrm{SE}, n=3)$} \\
\hline & & MSM & LSM & & & MSM & LSM \\
\hline 2008-04-21 & 0 & $281.58 \pm 25.98$ & $195.80 \pm 34.41$ & 2008-11-15 & 207 & $332.05 \pm 78.11$ & $177.05 \pm 65.55$ \\
\hline 2008-07-11 & 80 & $194.49 \pm 15.30$ & $110.17 \pm 9.58$ & 2009-04-26 & 371 & $216.31 \pm 14.24$ & $46.24 \pm 0.63$ \\
\hline 2008-08-09 & 109 & $190.50 \pm 11.15$ & $136.64 \pm 46.54$ & 2009-06-25 & 431 & $172.53 \pm 18.58$ & $52.92 \pm 5.55$ \\
\hline 2008-09-20 & 151 & $139.25 \pm 19.16$ & $104.69 \pm 12.06$ & 2009-08-25 & 492 & $177.07 \pm 9.04$ & $42.78 \pm 1.35$ \\
\hline 2008-10-20 & 181 & $191.51 \pm 44.05$ & $165.60 \pm 23.41$ & 2009-11-12 & 571 & $232.80 \pm 34.21$ & $66.97 \pm 8.79$ \\
\hline
\end{tabular}

MSM middle S. salsa marsh, LSM low S. salsa marsh

of $\mathrm{P}$ in $S$. salsa litter might also be ascribed to the $\mathrm{P}$ immobilization by microbes from the $\mathrm{P}$ sources (such as tidewater and topsoil) in the decomposition environment if the marsh was limited by P (Yang et al. 2006). As mentioned previously, since the LSM was more limited by $\mathrm{P}$, the $\mathrm{P}$ immobilization amounts in S. salsa litter in LSM were generally higher than those in MSM.

Studies showed that the decomposition rates of $S$. salsa litter in MSM and LSM were 0.3780 year $^{-1}$ and 1.1880 year $^{-1}$, respectively. Because the $S$. salsa litter in LSM could be decomposed completely within 1 year, the $\mathrm{P}$ standing crop of litter approximated $0 \mathrm{~g} \mathrm{~m}^{-2}$. The annual $\mathrm{P}$ release amount from litter to soil was about $0.0626 \mathrm{~g} \mathrm{~m}^{-2}$ year ${ }^{-1}$, indicating that the litter generally released $\mathrm{P}$ to the decomposition environment. By comparison, the $S$. salsa litter in MSM decomposed slowly and the annual $P$ return amount from litter to soil approximated $-0.0728 \mathrm{~g} \mathrm{~m}^{-2}$ year $^{-1}$ (minus represented immobilization), indicating that the litter immobilized $\mathrm{P}$ from the decomposition environment throughout the year. Because the actual input amounts of $S$. salsa litter in MSM and LSM were slightly more than 579.90 and $46.25 \mathrm{~g} \mathrm{~m}^{-2}$ as mentioned before, the theoretical $P$ release/immobilization amount should also be slightly more than 0.0626 and $-0.0728 \mathrm{~g} \mathrm{~m}^{-2}$ year $^{-1}$, respectively. However, since some litter was removed gradually by the tide and only part could be decomposed in situ, the actual $\mathrm{P}$ release/immobilization amount might be less than 0.0626 and $-0.0728 \mathrm{~g} \mathrm{~m}^{-2}$ year $^{-1}$. In LSM, because the P immobilized in the litter could be easily or gradually carried away by the tide, the $S$. salsa marsh might be lacking in $\mathrm{P}$, indicating that $\mathrm{P}$ might be an important limiting nutrient. This result was consistent with the conclusion mentioned above.

$\mathrm{P}$ allocation and cycle in plant-soil systems

\section{$P$ allocation in plant-soil systems}

Studying the allocation of $\mathrm{P}$ in the plant-soil systems of MSM and LSM showed that the aboveground living body was the main P stock of the plant subsystem with the mean values of 0.648 and $0.116 \mathrm{~g} \mathrm{~m}^{-2}$, accounting for 76.35 and $87.44 \%$ of the total $\mathrm{P}$ stock of the plant subsystems, respectively (Table 3). In the two plant-soil systems, the $\mathrm{P}$ stocks of the plant subsystem were very low, accounting for only 0.19 and $0.03 \%$ of the total P stock, respectively. Soil $\mathrm{P}$ was the main $\mathrm{P}$ stock of the two plant-soil systems, accounting for 99.81 and $99.97 \%$, respectively. The high proportion of soil $\mathrm{P}$ indicated that it was the circulation hinge in the process of $\mathrm{P}$ cycling, which could prevent the $\mathrm{P}$ from being lost easily. In addition, higher $\mathrm{P}$ stock of the plant subsystem and lower soil $\mathrm{P}$ and total $\mathrm{P}$ stock were generally observed in MSM compared to LSM (Table 3).

Establishment of P biological cycle pattern and assessment of $P$ cycle status

Based on the above-mentioned studies, the compartment pattern on the allocation and circulation of $\mathrm{P}$ in $S$. salsa marsh was established, and the quantitative relationships among compartments were determined (Fig. 7). According to the compartment pattern, this paper calculated the $\mathrm{P}$ absorption and cycle coefficients of $S$. salsa in MSM $(0.0010,0.739)$ and LSM $(0.0001,0.812)$, and compared them with the values of different plants in other marsh ecosystems in China (Table 4). Results showed that the P absorption coefficients were very low while the cycle coefficients were very high, indicating that the $\mathrm{P}$ absorbed by $S$. salsa was much lower compared with the P stock in soil. In addition, the limited P in $S$. salsa ecosystems had strong mobility and high biological cycle rates. As mentioned previously, because water and salinity are the most important environmental factors in the Yellow River estuary, the low $\mathrm{P}$ absorption capacities of $S$. salsa might be significantly affected by the intense inundation and high salinity conditions in tidal marshes.

The $\mathrm{P}$ absorption and cycle coefficients of the plants along the latitudinal gradient also had different variations (Table 4). The $\mathrm{P}$ absorption coefficients of different plants (Kandelia candel, Bruguiera sexangula, Rhizophora stylosa, Phragmites australis, S. alterniflora and Scirpus mariqueter) in the low or mid-low latitude regions $\left(19^{\circ} 51^{\prime}-31^{\circ} 14^{\prime} \mathrm{N}\right)$ were very low (0.0011-0.0117), while the cycle coefficients were generally high $(0.50-0.71)$. In the mid-high latitude region 
Table 3 Phosphorus allocation among compartments of Suaeda salsa marsh ecosystem

\begin{tabular}{|c|c|c|c|c|c|c|c|c|}
\hline \multirow[t]{2}{*}{ Type } & \multirow[t]{2}{*}{ Item } & \multirow[t]{2}{*}{ Root* } & \multicolumn{2}{|c|}{ Aboveground living body* } & \multirow[t]{2}{*}{ Litter* } & \multirow{2}{*}{$\begin{array}{l}\text { Plant } \\
\text { subsystem }\end{array}$} & \multirow{2}{*}{$\begin{array}{l}\text { Soil } \\
(0-60 \mathrm{~cm})^{* *}\end{array}$} & \multirow[t]{2}{*}{ Plant-soil system } \\
\hline & & & Stem & Leaf & & & & \\
\hline \multirow[t]{2}{*}{ MSM } & P stock $\left(\mathrm{g} \mathrm{m}^{-2}\right)$ & $0.079 \pm 0.016$ & $0.333 \pm 0.116$ & $0.315 \pm 0.114$ & $0.122 \pm 0.045$ & 0.849 & 438.83 & 439.68 \\
\hline & Percent $(\%)$ & $9.27^{\mathrm{a}}$ & $39.28^{\mathrm{a}}$ & $37.07^{\mathrm{a}}$ & $14.37^{\mathrm{a}}$ & $0.19^{\mathrm{b}}$ & $99.81^{\mathrm{b}}$ & $100^{\mathrm{b}}$ \\
\hline \multirow[t]{2}{*}{ LSM } & P stock $\left(\mathrm{g} \mathrm{m}^{-2}\right)$ & $0.007 \pm 0.001$ & $0.041 \pm 0.007$ & $0.075 \pm 0.018$ & $0.009 \pm 0.004$ & 0.133 & 492.27 & 492.40 \\
\hline & Percent $(\%)$ & $5.48^{\mathrm{a}}$ & $30.70^{\mathrm{a}}$ & $56.74^{\mathrm{a}}$ & $7.08^{\mathrm{a}}$ & $0.03^{\mathrm{b}}$ & $99.97^{\mathrm{b}}$ & $100^{\mathrm{b}}$ \\
\hline
\end{tabular}

MSM middle $S$. salsa marsh, LSM low S. salsa marsh

* Values are means $( \pm \mathrm{SE}, n=8)$

** Values are determined in August 2008

${ }^{a}$ Percent of plant subsystem

b Percent of plant-soil system

Fig. 7 Phosphorus biological cycle compartment pattern of the Suaeda salsa marsh ecosystems. Numerals in panes were the $\mathrm{P}$ stocks of compartments $\left(\mathrm{g} \mathrm{m}^{-2}\right)$, numerals above arrowhead were the $\mathrm{P}$ turnovers among compartments $\left(\mathrm{g} \mathrm{m}^{-2}\right.$ year $\left.^{-1}\right)$, *less than the value. ${ }^{\mathrm{M}} \mathrm{MSM}$ middle $S$. salsa marsh, ${ }^{\mathrm{L}} \mathrm{LSM}$ low $S$. salsa marsh, the minus represented $\mathrm{P}$ immobilization

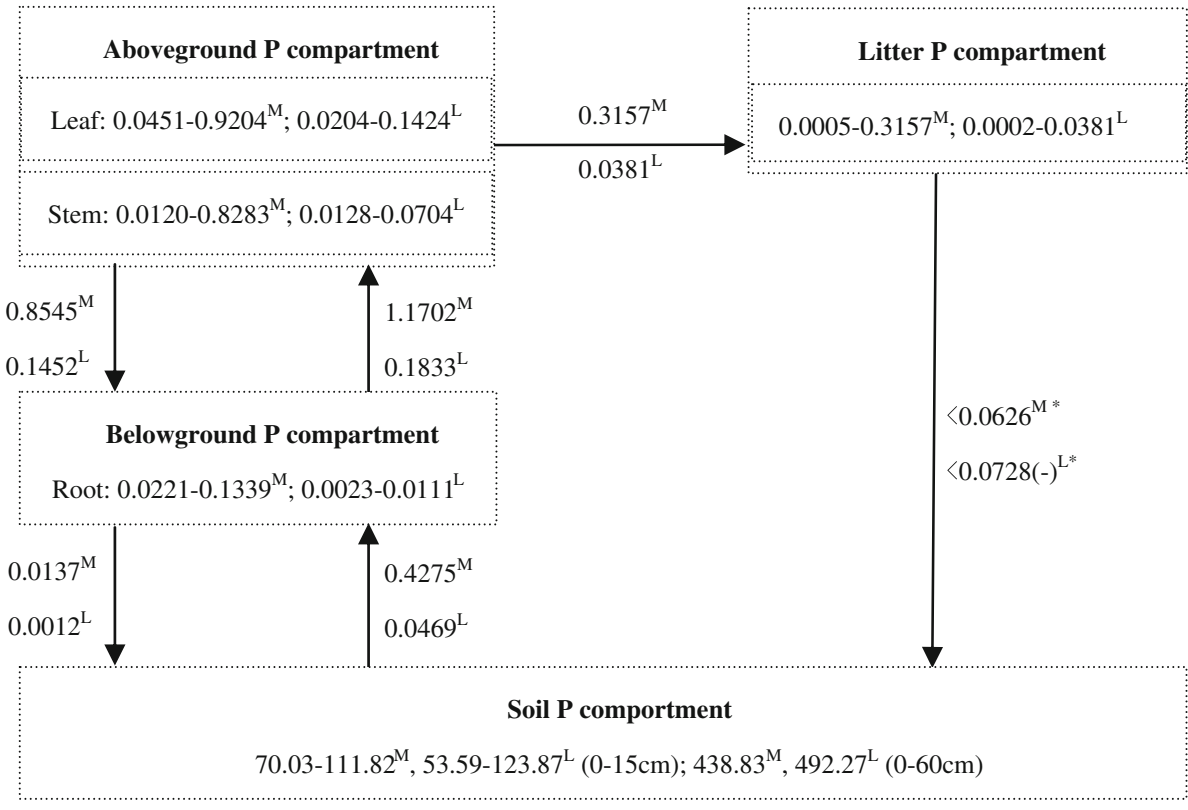

$\left(47^{\circ} 35^{\prime} \mathrm{N}\right)$, the absorption and cycle coefficients of different plants (C. angustifolia and Carex lasiocarpa) ranged from 0.352 to 0.634 and 0.091 to 0.352 , respectively. In this paper, the study site in the Yellow River estuary is located in the mid-low latitude region $\left(37^{\circ} 45^{\prime}-37^{\circ} 46^{\prime} \mathrm{N}\right)$, and the $\mathrm{P}$ absorption and cycle coefficients of $S$. salsa were generally in accordance with above-mentioned variations. The variations of cycle coefficients were mainly related to the regular changes of heat status, water conditions and precipitation along the latitudinal gradient, which had great influences on litter decomposition and nutrient recycling. Although temperature, water and precipitation might have some effects on plant growth, the $\mathrm{P}$ absorption capacities, to a great extent, depended on plant species, growth rhythm, eco-physiology characteristics, and the nutrient supply status in habitat (Qin 2008).
The evaluation of $\mathrm{P}$ biological cycle status indicated that $\mathrm{P}$ was an important limiting factor in $S$. salsa marshes, especially in LSM. S. salsa might exhibit a special adaptive strategy against the low-nutrient conditions and the vulnerable habitat. There were several probable reasons.

First, although the $\mathrm{P}$ stocks in MSM and LSM soils (0-60 cm) (438.83 and $492.27 \mathrm{~g} \mathrm{~m}^{-2}$, respectively) were generally higher than those of freshwater marsh and alpine tundra soils (Table 5), the $\mathrm{P}$ in tidal marshes was generally adsorbed or bound by clay, organic matter, $\mathrm{Fe}^{2+}$ and the hydroxide/oxide of aluminum (Wang and Liu 2002; Qu et al. 2010), which caused the supply of available $P$ in marsh soils to be limited. Moreover, since the $S$. salsa marsh was an open ecosystem frequently affected by the tide, the low available $\mathrm{P}$ in soil could be easily removed during the ebb and flow of the tide, which also might be an 
Table 4 Comparison of $\mathrm{P}$ absorption and cycle coefficients of the plants in different marsh ecosystems in China

\begin{tabular}{|c|c|c|c|c|c|c|}
\hline Location & Geographical location & Site & Plant & $\begin{array}{l}\text { Absorption } \\
\text { coefficient }\end{array}$ & $\begin{array}{l}\text { Cycle } \\
\text { coefficient }\end{array}$ & References \\
\hline \multirow[t]{3}{*}{ Sanjiang Plain } & \multirow[t]{3}{*}{$47^{\circ} 35^{\prime} 17^{\prime \prime} \mathrm{N}, 133^{\circ} 31^{\prime} 35^{\prime \prime} \mathrm{E}$} & \multirow[t]{3}{*}{ Honghe } & Carex lasiocarpa & 0.352 & 0.108 & He and Zhao (2001) \\
\hline & & & $\begin{array}{c}\text { Typical meadow } \\
\text { Calamagrostis } \\
\text { angustifolia }\end{array}$ & 0.634 & 0.352 & Qin (2008) \\
\hline & & & $\begin{array}{l}\text { Marsh meadow } \\
\text { C. angustifolia }\end{array}$ & 0.591 & 0.091 & \\
\hline \multirow[t]{3}{*}{ Yellow River estuary } & $37^{\circ} 45^{\prime} 57.0^{\prime \prime} \mathrm{N}, 119^{\circ} 09^{\prime} 40.7^{\prime \prime} \mathrm{E}$ & \multirow[t]{3}{*}{ Dawenliu } & Suaeda salsa & & & This study \\
\hline & $37^{\circ} 46^{\prime} 38.9^{\prime \prime} \mathrm{N}, 119^{\circ} 09^{\prime} 41.4^{\prime \prime} \mathrm{E}$ & & $\mathrm{A}^{*}$ & 0.0010 & 0.739 & \\
\hline & & & $\mathrm{B} * *$ & 0.0001 & 0.812 & \\
\hline \multirow[t]{9}{*}{$\begin{array}{l}\text { Yangtze River } \\
\text { estuary }\end{array}$} & \multirow[t]{9}{*}{$\begin{array}{l}31^{\circ} 06^{\prime} 20^{\prime \prime}-31^{\circ} 14^{\prime} 00^{\prime \prime} \mathrm{N} \\
121^{\circ} 53^{\prime} 06^{\prime \prime}-122^{\circ} 04^{\prime} 33^{\prime \prime} \mathrm{E}\end{array}$} & \multirow[t]{3}{*}{ Shangsha } & $\begin{array}{l}\text { Phragmites } \\
\text { australis }\end{array}$ & 0.0081 & 0.51 & $\begin{array}{l}\text { Liu and Yang } \\
\text { (2008) }\end{array}$ \\
\hline & & & $\begin{array}{l}\text { Spartina } \\
\text { alterniflora }\end{array}$ & 0.0056 & 0.72 & Yang et al. (2009a) \\
\hline & & & Scirpus mariqueter & 0.0067 & 0.59 & Yang et al. (2009b) \\
\hline & & \multirow[t]{3}{*}{ Zhongsha } & P. australis & 0.0091 & 0.53 & $\begin{array}{l}\text { Liu and Yang } \\
\text { (2008) }\end{array}$ \\
\hline & & & S. alterniflora & 0.0117 & 0.71 & Yang et al. (2009a) \\
\hline & & & S. mariqueter & 0.0042 & 0.65 & Yang et al. (2009b) \\
\hline & & \multirow[t]{3}{*}{ Xiasha } & P. australis & 0.0031 & 0.36 & $\begin{array}{l}\text { Liu and Yang } \\
\text { (2008) }\end{array}$ \\
\hline & & & S. alterniflora & 0.0053 & 0.62 & Yang et al. (2009a) \\
\hline & & & S. mariqueter & 0.0011 & 0.11 & Yang et al. (2009b) \\
\hline Jiulong River estuary & $\begin{array}{l}24^{\circ} 26^{\prime} 10^{\prime \prime}-24^{\circ} 27^{\prime} 38^{\prime \prime} \mathrm{N}, \\
117^{\circ} 54^{\prime} 12^{\prime \prime}-117^{\circ} 55^{\prime} 31^{\prime \prime} \mathrm{E}\end{array}$ & Longhai & Kandelia candel & - & $0.500 * * *$ & Lin (2001) \\
\hline Shatian Peninsula & $\begin{array}{l}21^{\circ} 28^{\prime} 22^{\prime \prime}-21^{\circ} 37^{\prime} 00^{\prime \prime} \mathrm{N} \\
109^{\circ} 37^{\prime} 00^{\prime \prime}-109^{\circ} 47^{\prime} 00^{\prime \prime} \mathrm{E}\end{array}$ & Shatian & $\begin{array}{l}\text { Bruguiera } \\
\text { sexangula }\end{array}$ & - & $0.583 * * *$ & \\
\hline Hainan Island & $\begin{array}{l}19^{\circ} 51^{\prime}-20^{\circ} 01^{\prime} \mathrm{N}, 110^{\circ} 32^{\prime}- \\
110^{\circ} 37^{\prime} \mathrm{E}\end{array}$ & Dongzhaigang & Rhizophora stylosa & - & $0.462 * * *$ & \\
\hline
\end{tabular}

* Suaeda salsa in middle marsh

** S. salsa in low marsh

*** Coefficients were calculated according to the data in reference

important cause of the low $\mathrm{P}$ absorption coefficient of S. salsa.

Second, litter decomposition was generally regarded as an effective way for nutrient return; however, this study drew different conclusions. In MSM, the $S$. salsa litter released $\mathrm{P}$ to the environment throughout the year, with an annual $\mathrm{P}$ return amount of $0.0626 \mathrm{~g} \mathrm{~m}^{-2}$. Since $S$. salsa litter was gradually removed by the tide and the release of $\mathrm{P}$ from litter to soil was also influenced by the tide, the actual $\mathrm{P}$ return amount was far lower than $0.0626 \mathrm{~g} \mathrm{~m}^{-2}$. By contrast, the $S$. salsa litter in LSM immobilized $\mathrm{P}$ from the environment at all times during decomposition (with an annual P immobilization amount of $0.0728 \mathrm{~g} \mathrm{~m}^{-2}$ ), and the litter could also be easily or gradually carried away by the tide, indicating that the litter in LSM acted as an important source of P loss. This also might be an important reason to conclude that the $S$. salsa in LSM was especially limited by P.
Third, the P absorption capacities of $S$. salsa in MSM and LSM were very low and intense inundation or high salinity might inhibit the capacity as mentioned above, indicating that the $S$. salsa in tidal marshes (especially in LSM) was very limited by P. This result was consistent with the conclusion drawn by the study of N/P ratios in S. salsa.

Based on the above analysis, the available $\mathrm{P}$ was very limited in $S$. salsa marshes, indicating that the ecosystems were lacking in P. Moreover, the P in S. salsa marshes had high biological cycle rates, which indicated that the lack of $\mathrm{P}$ might be very severe.

Mistch and Gosselin (2000) indicated that $\mathrm{N}$ and $\mathrm{P}$ are often the most limiting nutrients in marshes, and the cycle status of $\mathrm{N}$ or P not only affects the structure and function of marshes, but also, to some extent, influences the stabilization and health of ecosystems. In this sense, the current $S$. salsa marsh was unstable and vulnerable. However, the $S$. salsa 
Table 5 Comparison of $\mathrm{P}$ stocks in freshwater marsh, tidal marsh and alpine tundra soils

\begin{tabular}{|c|c|c|c|c|c|}
\hline Type & Site & Plant & $\begin{array}{l}\text { P stock } \\
\left(\mathrm{g} \mathrm{m}^{-2}\right)\end{array}$ & $\begin{array}{l}\text { Soil depth } \\
(\mathrm{cm})\end{array}$ & References \\
\hline \multirow{2}{*}{$\begin{array}{l}\text { Freshwater marsh } \\
\text { ecosystem }\end{array}$} & \multirow[t]{2}{*}{ Sanjiang Plain } & Typical meadow $C$. angustifolia & 443.18 & \multirow[t]{2}{*}{$0-60$} & \multirow[t]{2}{*}{ Qin (2008) } \\
\hline & & Marsh meadow $C$. angustifolia & 371.98 & & \\
\hline \multirow[t]{5}{*}{ Tidal marsh ecosystem } & \multirow{5}{*}{$\begin{array}{l}\text { Yellow River } \\
\text { estuary }\end{array}$} & Suaeda salsa & & & \multirow[t]{5}{*}{ This study } \\
\hline & & $\mathrm{A}^{*}$ & $70.03-111.82$ & $0-15$ & \\
\hline & & $\mathrm{B} * *$ & $53.59-123.87$ & & \\
\hline & & $\mathrm{A}^{*}$ & 438.83 & $0-60$ & \\
\hline & & $\mathrm{B} * *$ & 492.27 & & \\
\hline \multirow[t]{10}{*}{ Alpine tundra ecosystem } & \multirow[t]{10}{*}{ Changbai Mountain } & Felsenmeer alpine tundra & 59 & $0-10$ & \multirow[t]{10}{*}{ Wei et al. (2005) } \\
\hline & & vegetation & 46 & $10-20$ & \\
\hline & & Lithic alpine tundra vegetation & 25 & $0-10$ & \\
\hline & & & 24 & $10-20$ & \\
\hline & & Typical alpine tundra vegetation & 62 & $0-10$ & \\
\hline & & & 64 & $10-20$ & \\
\hline & & Meadow alpine tundra vegetation & 76 & $0-10$ & \\
\hline & & & 90 & $10-20$ & \\
\hline & & Swamp alpine tundra vegetation & 62 & $0-10$ & \\
\hline & & & 78 & $10-20$ & \\
\hline
\end{tabular}

* Suaeda salsa in middle marsh

** S. salsa in low marsh

was seemingly well adapted to the low-nutrient condition and the vulnerable habitat. At present, the import of $\mathrm{N}$ and $\mathrm{P}$ from the Yellow River estuary is increasing due to human activities (Bulletin of Shandong Oceanic Environmental Quality 2009). Loading of excessive N and P to the estuary ecosystem may cause changes in ecological function, and often has undesirable environmental and economic consequences (Sun and Liu 2008). As $S$. salsa is probably well adapted to the low-nutrient environment, the nutrient enrichment is a potential threat to the $S$. salsa marshes. Excessive nutrient loading from the Yellow River estuary may lead to the invasion of nutrient-rich species (such as Phragmites australis, Triarrhena sacchariflora and Tamarix chinensis) and cause severe degradation of the ecosystem in the long-term if measures are not taken.

\section{Conclusions}

This paper established the $\mathrm{P}$ biological cycle compartment pattern of the two S. salsa marshes (MSM and LSM) in the intertidal zone of the Yellow River estuary, and evaluated the P cycle status of ecosystems. Results have demonstrated that: (i) the P uptake amounts of roots were 0.4275 and $0.0469 \mathrm{~g} \mathrm{~m}^{-2}$ year $^{-1}$ and the values of aboveground parts were 1.1702 and $0.1833 \mathrm{~g} \mathrm{~m}^{-2}$ year $^{-1}$, the re-translocation quantities from aboveground parts to roots were
0.8544 and $0.1452 \mathrm{~g} \mathrm{~m}^{-2}$ year $^{-1}$, the translocation quantities from roots to soil were 0.0137 and $0.0012 \mathrm{~g} \mathrm{~m}^{-2}$ year $^{-1}$, the translocation amounts from aboveground living bodies to litter were 0.3157 and $0.0381 \mathrm{~g} \mathrm{~m}^{-2} \mathrm{year}^{-1}$, and the annual return quantities from litter to soil were less than 0.0626 and $-0.0728 \mathrm{~g} \mathrm{~m}^{-2}$ year $^{-1}$ (minus represented immobilization), respectively; (ii) the $\mathrm{P}$ in $S$. salsa marshes (especially in LSM) was an important limiting factor. The $S$. salsa was seemingly well adapted to the low-nutrient condition and the vulnerable habitat, and the nutrient enrichment due to the import of $\mathrm{N}$ and $\mathrm{P}$ from the Yellow River estuary would be a potential threat to the $S$. salsa marshes.

Acknowledgments The authors would like to acknowledge the financial support of the Ocean Public Welfare Scientific Research Project, State Oceanic Administration, People's Republic of China (No. 2012418008-3), National Nature Science Foundation of China (No. 41171424, 40803023), the Key Program of Natural Science Foundation of Shandong Province (No. ZR2010DZ001), the Strategy Guidance Program of the Chinese Academy of Sciences (No. XD05030404), the Talents Program of the Youth Innovation Promotion Association, Chinese Academy of Sciences (No. Y129091041), and the Innovation Program of the Chinese Academy of Sciences (No. KZCX2YW-223).

Open Access This article is distributed under the terms of the Creative Commons Attribution License which permits any use, distribution, and reproduction in any medium, provided the original author(s) and the source are credited. 


\section{References}

Bai JH, Deng W, Wang QG, Ding QW (2007) Seasonal dynamics of carbon, nitrogen and phosphorous in soil profiles from an inland salt marsh. J Lake Sci 19(5):599-603

Braekke FH (1990) Nutrient accumulation and role of atmospheric deposition in coniferous stands. Forest Ecol Manag 30(1-4):351-359

Bragato C, Brix H, Malagoli M (2006) Accumulation of nutrients and heavy metals in Phragmites australis (Cav.) Trin. ex Steudel and Bolboschoenus maritimus (L.) Palla in a constructed wetland of the Venice lagoon watershed. Environ Pollut 144:967-975

Bulletin of Shandong Oceanic Environmental Quality (2009) http://www.soa.gov.cn/soa/hygb/yhgb/nine/webinfo/2010/06/ $1281687829218830 . \mathrm{htm}$

Chen LZ, Lindley DK (1983) Nutrient elements cycling in Pteridium aquilinum grassland ecosystem of Hampsfe, England. Acta Ecol Sin 25(1):67-74

Coelho JP, Flindt MR, Jensen HS, Lillebo AI, Pardal MA (2004) Phosphorus speciation and availability in intertidal sediments of a temperate estuary: relation to eutrophication and annual P-fluxes. Estuar Coast Shelf S 61:583-590

Compton JS, Mallinson DJ, Glenn CR, Filippelli G, Follmi K, Shields G, Zanin Y (2000). Variations in the global phosphorus cycle. In: Glenn CR (ed) Marine authigenesis: from global to microbial society of sedimentary geology, Special Publication Number, 66:22-33

Cui BS, Yang QC, Yang ZF, Zhang KJ (2009) Evaluating the ecological performance of wetland restoration in the Yellow River Delta, China. Ecol Eng 35:1090-1103

Dahlman RC, Kucera CL (1965) Root productivity and turnover in native prairie. Ecology 46:84-89

Davis SM (1991) Growth, decomposition, and nutrient retention of Cladium jamaicense Crantz and Typha domingensis Pers. in the Florida Everglades. Aquat Bot 40(3):203-224

Dunne EJ, Smith J, Perkins DB, Clark MW, Jawitz JW, Reddy KR (2007) Phosphorus storages in historically isolated wetland ecosystems and surrounding pasture uplands. Ecol Eng 31:16-28

Gu FT (1998) Research in exploiting the green series of ediblesSuaeda salsa. J Binzhou Edu Coll 5:43-48

Han N, Shao Q, Lu CM, Wang BS (2005) The leaf tonoplast V-H $\mathrm{H}^{+}$ ATPase activity of a $\mathrm{C}_{3}$ halophyte Suaeda salsa is enhanced by salt stress n a Ca-dependent mode. J Plant Physiol 162:267-274

He CQ, Zhao KY (2001) The accumulation, allocation and biological cycle of the nutrient elements in Carex lasiocarpa wetland. Acta Ecol Sin 21(12):2074-2080

He HB, Li Y (2008) Study on measures of biomass allocation of two desert halophyte species under drought and salt stress. Arid Zone Res 25(2):242-247

Hinsinger P (2001) Bioavailability of soil inorganic $P$ in the rhizosphere as affected by root-induced chemical changes: a review. Plant Soil 237:173-195

Hogan DM, Jordan TE, Walbridge MR (2004) Phosphorus retention and soil organic carbon in restored and natural freshwater wetlands. Wetlands 24:573-585

Jiménez-Cárceles FJ, Álvarez-Rogel J (2008) Phosphorus fractionation and distribution in salt marsh soils affected by mine waste and eutrophicated water: a case study in SE Spain. Geoderma 144:299-309

Koerselman W, Meuleman AFM (1996) The vegetation N:P ratio: a new model tool to detect the nature of nutrient limitation. J Appl Ecol 33:1441-1450

Li YS, Redmann RE (1992) Nitrogen budget of Agropyron dasystachyum in Canadian mixed prairie. Am Midl Nat 128:61-71

Li YZ, Wang QS, Zhong XL, Ren N (2003) N internal cycling in Leymus chinensis grassland vegetation-soil system. Acta Phytoecol Sin 27(2):177-182
Lin P (2001) A review on the mangrove research in China. J. Xiamen Univ (Nat Sci) 40(2):592-603

Liu JS, Li XH (2008) Sulfur cycle in the typical meadow Calamagrostis angustifolia wetland ecosystem in the Sanjiang Plain, Northeast China. J Environ Sci 20:470-475

Liu CE, Yang YX (2008) Characteristics of N, P and K cycling in Phragmites australis wetland ecosystem in Jiuduansha shoal of Shanghai. Chin J Appl Ecol 27(3):418-424

Liu JS, Sun XL, Yu JB (2000) Nitrogen content variation in litters of Deyeuxia angustifolia and Carex lasiocarpa in Sanjiang Plain. Chin J Appl Ecol 11(6):898-902

Liu JS, Yu JB (2005) Element cycling in the dominant plant community in the Alpine tundra zone of Changbai Mountains, China. J Environ Sci 17(3):521-525

Liu Y, Ding TL, Wang BS (2006) Study on the leaf succulence of Sueada salsa under different natural saline environments. J Shandong Norm Univ (Nat Sci) 21(2):102-104

Lu JL (2003) Plant nutrient. China Agricultural University Press, Beijing, pp 35-48

Mistch WJ, Gosselin JG (2000) Wetlands. Van Nostrand Reinhold Company Inc, New York

Mou XJ (2010) Study on the nitrogen biological cycling characteristics and cycling model of tidal wetland ecosystem in Yellow River estuary. Master degree dissertation, Yantai Institute of Coastal Zone Research, Chinese Academy of Sciences, Yantai

Mou XJ, Sun ZG, Wang LL, Dong HF (2010) Characteristics of nitrogen accumulation and allocation of Suaeda salsa in different growth conditions of intertidal zone in Yellow River estuary. Wetland Sci 8(1):57-66

Newman JM, Lynch T (2001) The Everglades nutrient removal project test cells: STA optimization-status of the research at the north site. Water Sci Technol 44:117-122

Niedermeier A, Robinson JS (2009) Phosphorus dynamics in the ditch system of a restored peat wetland. Agr Ecosyst Environ 131:161-169

Nielsen T, Andersen FØ (2003) Phosphorus dynamics during decomposition of mangrove (Rhizophora apiculata) leaves in sediments. J Exp Mar Biol Ecol 293:73-88

Olson JS (1963) Energy storage and the balance of products and decomposers in ecological systems. Ecology 44(2):322-331

Qin SJ (2008) Study on the phosphorus transference and transformation process of Calamagrostis angustifolia wetland in the Sanjian Plain. Doctor degree dissertation, Northeast Institute of Geography and Agroecology, Chinese Academy of Sciences, Changchun

Qin SJ, Liu JS, Sun ZG (2006a) Dynamics of phosphorus and biomass accumulation of Calamagrostis angustifolia in Sanjiang Plain. Chin J Appl Ecol 25(6):646-651

Qin SJ, Liu JS, Wang GP (2006b) Mechanism of phosphorus availability changing in soil. Chin J Soil Sci 37(5):1012-1016

Qin SJ, Liu JS, Wang GP, Zhou WM (2007) Phosphorus fractions under different land uses in Sanjiang Plain. Environ Sci 28(12):2777-2782

Qu FZ, Yu JB, Meng L, Xu G (2010) Resin-P and its distribution profile in the Suaeda salsa community soil in the Yellow River Delta coastal wetland. J Soil Water Conserv 24(6):150-152

Rawat JS, Banerjee SP (1998) The influence of salinity on growth, biomass production and photosynthesis of Eucalyptus camaldulensis Dehnh. and Dalbergia sissoo Roxb. seedlings. Plant Soil 205:163-169

Reuss JO, Innis GS (1977) A grassland nitrogen flow simulation model. Ecology 58:379-388

Ruan Y, Liu Y, Wang BS (2008) Study on the pigment accumulation and characteristics of photosynthesis of Suaeda salsa under different natural saline environments. J Shandong Norm Univ (Nat Sci) 23(1):115-117 
Stribling JM, Cornwell JC (2001) Nitrogen, phosphorus, and sulfur dynamics in a low salinity marsh system dominated by Spartina alterniflora. Wetlands 21(4):629-638

Sun ZG, Liu JS (2007) Nitrogen cycling of atmosphere-plant-soil system in the Calamagrostis angustifolia wetland in the Sanjiang Plain, Northeast China. J Environ Sci 19:986-995

Sun ZG, Liu JS (2008) Distribution and fate of anthropogenic nitrogen in the Calamagrostis angustifolia wetland ecosystem of Sanjiang Plain, Northeast China. J Integr Plant Biol 50(4):402-414

Sun ZG, Qin SJ, Liu JS, Wang JD (2007) Biomass structure and nitrogen, phosphorus nutrient of Calamagrostis angustifolia populations in different communities of Sanjiang Plain, Northeast China. Fornt For China 2(4):366-375

Tessier JT, Raynal DJ (2003) Use of nitrogen to phosphorus ratios in plant tissue as an indicator of nutrient limitation and nitrogen saturation. J Appl Ecol 40:523-534

The Committee of Agro-chemistry of the Chinese Society of Soil Science (1983) The conventional analysis methods in soil agrochemistry. Science Press, Beijing

Tian HQ, Chen GS, Zhang C, Melillo JM, Hall C (2010) Pattern and variation of $\mathrm{C}: \mathrm{N}: \mathrm{P}$ ratios in China's soils: a synthesis of observational data. Biogeochemistry 98:139-151

Tian JY, Wang XF, Cai XJ (2005) Protection and restoration technique of wetland ecosystem in Yellow River Delta. China Ocean University Press, Qingdao

Walbridge MR (2000) Phosphorus biogeochemistry. Ecology $81: 1474-1475$

Wallance A, Romney EM, Kleinkopf GE (1978) Uptake of mineral forms of nitrogen by desert plants. In: West NE, Skujins JJ (eds) Nitrogen in desert ecosystems. Hutchinson and Ross, Dowden, $130-151$

Wang GP, Liu JS (2002) Overview on wetland biogeochemistry. J Soil Water Conserv 16(4):144-148

Wang CQ, Zhao JQ, Chen M, Wang BS (2006) Identification of betacyanin and effects of environmental factors on its accumulation in halophyte Suaeda salsa. J Plant Physiol Mol Biol 32:195-201

Wang LL, Hu JM, Song CC, Yang T (2008) Influences of water gradients on the aboveground biomass of a typical wetland plant
(Calamagrostis angustifolia) in the Sanjiang Plain. Acta Pratacul Sin 17(4):19-25

Wang Q, Sun JX, An Y (2009) The effect of the population properties and stress-tolerance physiological characteristics of Zoysia grass under water stresses. Acta Pratacul Sin 18(2):33-38

Wei J, Wu G, Wang H, Hao YJ, Shang WY (2005) Phosphorus and sulphur bio-cycling in alpine tundra ecosystem of Changbai Mountains. Chin J Appl Ecol 16(7):1230-1234

Wu G, Wei J, Deng HB, Zhao JZ (2006) Nutrient cycling in an Alpine tundra ecosystem on Changbai Mountain, Northeast China. Appl Soil Ecol 32(2):2087-2092

Xiao R, Bai JH, Zhang HG, Gao HF, Liu XH, Andreas W (2011) Changes of $\mathrm{P}, \mathrm{Ca}, \mathrm{Al}$ and $\mathrm{Fe}$ contents in fringe marshes along a pedogenic chronosequence in the Pearl River estuary, South China. Cont Shelf Res 31(6):739-747

Xiao R, Bai JH, Gao HF, Huang LB, Deng W (2012) Spatial distribution of phosphorus in marsh soils of a typical land/inland water ecotone along a hydrological gradient. Catena 98:96-103

Xu XG, Guo HH, Chen XL, Lin HP, Du QL (2002) A multi-scale study on land use and land cover quality change: the case of the Yellow River Delta in China. GeoJournal 56(3):177-183

Yang JS, Liu JS, Yu JB, Wang JD, Li XH, Sun ZG (2006) Decomposition and nutrient dynamics of marsh litter in the Sanjiang Plain, Northeast China. Acta Ecol Sin 26(5):1297-1302

Yang YX, Liu CE, Yang Y (2009a) Characteristics of N, P and K cycling in Spartina alterniflora wetland ecosystem in Jiuduansha shoal of Yangtze River estuary. Chin J Appl Ecol 28(2):223-230

Yang YX, Liu CE, Yang Y (2009b) Characteristics of N, P and K cycling in Scirpus mariqueter wetland ecosystem at Jiuduansha shoal of Yangtze River estuary. Chin J Appl Ecol 28(10):1977-1985

Zhang C, Tian HQ, Liu J, Wang S, Liu M, Pan S, Shi X (2005). Pools and distributions of soil phosphorus in China. Global Biogeochem Cy 19:GB1020

Zhang J, Li M, Liu S, Liu YJ, Zhang LQ, Cao Q, Sun DZ (2011) Seasonal variations and bioavailability of inorganic phosphorus in soils of Yeyahu Wetland in Beijing, China. Int J Sediment Res 26(2):181-192 